\title{
IMPACT OF HOUSING CONDITIONS ON THE PRODUCTIVE PERFORMANCE AND PHYSIOLOGICAL RESPONSES OF GROWING NZW RABBITS
}

\author{
A.H.H. Ali and A.A.A. Abdel-Wareth* \\ Department of Animal and Poultry Production, Faculty of Agriculture, South Valley University, 83523 Qena, \\ Egypt \\ *corresponding author email: a.wareth@agr.svu.edu.eg
}

\section{SUMMARY}

The current study was conducted investigated to evaluate the effects of two housing systems on growth performance, carcass traits, and physiological responses of growing rabbits during 28 to 118 days of age under summer conditions of Upper Egypt. A total of $80 \mathrm{New}$ Zealand White Rabbits, 4 weeks old, were housed individually in metabolic wire cages. Forty rabbits were reared in open house system (OHS) $\left(36^{\circ} \mathrm{C}\right.$ average ambient temperatures and $20 \%$ relative humidity) and 40 rabbits were reared in closed house system (CHS) (Constant temperature of $22{ }^{\circ} \mathrm{C}$ and $60 \%$ relative humidity). At 118 days, 10 rabbits per treatment were slaughtered and carcass traits and blood parameters were evaluated. The results showed that rabbits reared in OHS had significantly $(P<0.05)$ lower final body weight, daily feed intake and daily body gain as well as inferior feed conversion ratio compared to rabbits housed in CHS. Neither OHS nor CHS Housing system had no significant effects on most of blood parameters. Spleen $\%$ and kidney\% were significantly $(P<0.05)$ decreased and intestine percentage was significantly $(P<0.05)$ increased in rabbits reared in OHS when compared to rabbits housed in $\mathrm{CHS}$.

It can be stated that rabbits reared in OHS in dry tropical conditions decreased growth performance and had no any significant effects on most of the carcass traits. However, more research is needed in future to evaluate reproductive performance and economical return of rabbits raised under Upper Egypt climate.

Keywords: Rabbits, growth performance, carcass traits, blood parameters, housing conditions systems

\section{INTRODUCTION}

Rabbit meat has several advantages that support the increase of its use for human consumption (Dacinia-Crina et al., 2013). The need for meat will increase in the following decades, especially in developing countries (Kanaly et al., 2010). This requires the increase of the production of livestock to meet the protein demand from the population. Rabbits are characterized by small body size, high growth rate, high efficiency in converting feed into meat, short gestation period, and high prolificacy, relatively low cost of production and high nutritional quality of its meat which includes low fat, sodium and cholesterol levels (Marai et al., 1991). Rabbit meat is competitive with other types of meat both qualitatively and nutritionally. Moreover, the raw materials required to formulate rabbit feeds are different from those required for human consumption (Casimiro et al., 1991). For these reasons, the development of intensive rabbit rearing in Egypt is to be considered welcomed, especially where there are no opposing factors of social, cultural or religious nature regarding the breeding technology. One of the main problems with this species is its sensitivity to high temperatures and dry weather. The weather in Upper Egypt in the summer is hot and dry which means that the temperature could reach $45^{\circ} \mathrm{C}$. Peak temperatures in Upper Egypt from May to October are usually compensated for by extremely low humidity.

The objective of this study is thus concerned on how the rabbit cools itself through providing the most comfortable environment for rabbits in hot and dry weather to prevent heat stress. Therefore, this study was conducted in Upper Egypt (Qena) to evaluate growth performance, feed efficiency, liver function, hematological and biochemical parameters of New Zealand White Rabbits under open and closed housing systems.

\section{MATERIALS AND METHODS}

\section{Animals and experimental design:}

Eighty growing New Zealand White Rabbits, at four weeks of age, just after weaning, with an average body weight (BW) of about $662 \mathrm{~g}$ were used. The rabbits were divided at random into two equal groups, 40 rabbits were reared in open house system (OHS) (naturally ventilated room by windows and ceiling fans) with average temperature of $36.81 \pm 2{ }^{\circ} \mathrm{C}$ and a relative humidity (R.H) ranged from 25-32\% during the whole period of the experiment. The second group, 40 rabbits were housed in a closed (CHS) and well ventilated block building with a constant temperature of $22 \pm 2{ }^{\circ} \mathrm{C}$ and R.H. $60 \%$, therefore the temperature-humidity index (THI) was 21 which according to the following equation is absence of heat stress. Air temperature $\left({ }^{\circ} \mathrm{C}\right)$ and relative humidity $(\%)$ were measured four times each month at $7.00 \mathrm{am}$ and $2.00 \mathrm{pm}$. The temperaturehumidity index (THI) was calculated (Table 1) using the equation modified by Marai et al. (2001):

$\mathrm{THI}=\mathrm{db}^{\circ} \mathrm{C}-\left[(0.31-0.31 \mathrm{RH})\left(\mathrm{db}^{\circ} \mathrm{C}-14.4\right)\right]$, Where:

$\mathrm{db}^{\circ} \mathrm{C}=$ dry bulb temperature in Celsius

$\mathrm{RH}=$ relative humidity percentage/100. 
The THI values obtained were then classified as follows: $<27.8=$ absence of heat stress, $27.8-<28.9=$ moderate heat stress, $28.9-<30.0=$ severe heat stress and 30.0 and more $=$ very severe heat stress (Marai et al., 2001).

Both groups were housed individually for 90 days (from June to August) in galvanized batteries provided with feeders and automatic drinkers. Fresh water was automatically available at all time by stainless steel nipples for each cage. Feed in pelleted form were provided ad libitum. Composition and nutritive value of rabbits feed are given in Table (2).

Table 1. The temperature-humidity index (THI) during the experimental period in open house system

\begin{tabular}{|c|c|c|c|c|c|c|c|c|c|}
\hline & \multicolumn{2}{|c|}{$7: 00 \mathrm{~h}$} & \multicolumn{2}{|c|}{ 14:00 h } & \multicolumn{2}{|c|}{ Mean } & \multirow{2}{*}{$\begin{array}{l}\text { ThI } \\
\text { 7:00 }\end{array}$} & \multirow{2}{*}{$\begin{array}{c}\text { ThI } \\
\text { 14:00 }\end{array}$} & \multirow{2}{*}{$\begin{array}{c}\text { ThI } \\
\text { Average }\end{array}$} \\
\hline & Temp & RH & Temp & RH & Temp & RH & & & \\
\hline June & 28.89 & 31.07 & 36.01 & 17.97 & 32.45 & 24.52 & 25.80 & 30.51 & 28.23 \\
\hline July & 28.98 & 35.32 & 36.21 & 23.64 & 32.60 & 29.48 & 26.06 & 31.05 & 28.62 \\
\hline August & 28.17 & 34.42 & 35.11 & 23.64 & 31.64 & 29.03 & 25.37 & 30.21 & 27.85 \\
\hline Mean & 28.68 & 33.60 & 35.78 & 21.75 & 32.23 & 27.68 & 25.74 & 30.59 & 28.23 \\
\hline
\end{tabular}

Temp: temperature in Celsius $\mathrm{RH}$ : relative humidity percentage/100.

Table 2. Composition and nutritive value of growing rabbit's diet

\begin{tabular}{|c|c|c|c|}
\hline \multicolumn{2}{|l|}{ Ingredients } & \multicolumn{2}{|c|}{$\%$} \\
\hline \multicolumn{2}{|l|}{ Yellow corn } & \multicolumn{2}{|c|}{32.0} \\
\hline & \multicolumn{2}{|c|}{20.0} \\
\hline & Soybean meal (44\%) & \multicolumn{2}{|c|}{18.0} \\
\hline \multicolumn{2}{|c|}{ Wheat straw } & \multicolumn{2}{|c|}{12.0} \\
\hline \multicolumn{2}{|l|}{ Alfalfa hay } & \multicolumn{2}{|c|}{5.0} \\
\hline \multicolumn{2}{|c|}{ Rice bran } & \multicolumn{2}{|c|}{5.0} \\
\hline \multicolumn{2}{|c|}{ Linseed straw } & \multicolumn{2}{|c|}{2.8} \\
\hline \multicolumn{2}{|c|}{ Sunflower meal } & \multicolumn{2}{|c|}{2.5} \\
\hline \multicolumn{2}{|c|}{ Lime stone } & \multicolumn{2}{|c|}{2.0} \\
\hline \multicolumn{2}{|c|}{ Sodium chloride } & \multicolumn{2}{|c|}{0.3} \\
\hline \multicolumn{2}{|c|}{ Vitamins and minerals premix* } & \multicolumn{2}{|c|}{0.3} \\
\hline \multicolumn{2}{|c|}{ DL-Methionine } & \multicolumn{2}{|c|}{0.1} \\
\hline \multicolumn{2}{|c|}{ Total } & \multicolumn{2}{|c|}{100} \\
\hline \multicolumn{4}{|c|}{ Nutritive value in dry matter: } \\
\hline \multicolumn{2}{|c|}{$\mathrm{DE}(\mathrm{Kal} / \mathrm{Kg})$} & \multicolumn{2}{|c|}{2463} \\
\hline \multicolumn{2}{|l|}{$\mathrm{CP} \%$} & \multicolumn{2}{|c|}{16.35} \\
\hline \multicolumn{2}{|l|}{$\mathrm{CF} \%$} & \multicolumn{2}{|c|}{11.54} \\
\hline Vitamins an & & Vitamins an & \\
\hline Vitamin A & $10.000 \mathrm{IU}$ & Zinc & $70 \mathrm{mg}$ \\
\hline Vitamin D & $3.900 \mathrm{IU}$ & Copper & $0.1 \mathrm{mg}$ \\
\hline Vitamin E & $50.0 \mathrm{mg}$ & Manganese & $8.5 \mathrm{mg}$ \\
\hline Vitamin $\mathrm{K}$ & $2.0 \mathrm{mg}$ & Ferrous & $75.0 \mathrm{mg}$ \\
\hline Vitamin B1 & $2.0 \mathrm{mg}$ & Folic acid & $5.0 \mathrm{mg}$ \\
\hline
\end{tabular}

Productive traits:

Body gain and feed intake:

The individual body weights (IBW) and feed intakes of the rabbits were recorded weekly to determine the daily weight gain (DWG). The daily feed intake (DFI) was determined and the feed conversion ratio (FCR) was calculated according to the following equation: FCR = DFI $(\mathrm{g}) / \mathrm{DWG}(\mathrm{g})$.

Mortality rate (MR \%) was recorded as it occurred.

\section{Carcass characteristics:}

At the end of the experiment, ten representative rabbits from each group were starved for about eight hours before slaughter, to empty the gut as far as possible. They were well watered during this period to prevent dehydration and weight loss. Slaughter weight (SW) was recorded when bleeding was completed. The hind legs were held firmly in the left hand, with the right hand holding the rabbit's head directly behind the ears. Skinning and dressing the carcass were carried out while the rabbit was suspended from a horizontal rail or a bar (Aduku and Olukosi, 1990). Evisceration was carried out by making a longitudinal cut through the body wall from the vent through the belly to the breast bone. The gut, lungs, heart, liver, kidneys and abdominal fat were removed through this cavity. Weight of the liver, heart, lungs, head, thyroid gland and spleen and weight and length of empty small and large intestine (gastro intestinal tract GIT) were recorded. Abdominal fat in relation to carcass weight was also estimated.

\section{Physiological traits:}

At the end of the experimental period, five representative rabbits of each treatment were anaesthetized by intraperitoneal administration of pentobarbital $(60 \mathrm{mg} / \mathrm{kg} \mathrm{BW})$. Blood samples were harvested from the rabbit ear veins by 22-gauge syringes. Selected hematological parameters in whole blood including total white blood cell count (WBC), lymphocytes count (LYM), medium size cell count 
(MID), granulocytes count (GRA), lymphocyte percentage (LYM\%), medium size cell percentage (MID\%), granulocytes percentage (GRA\%), red blood cell count (RBC), haemoglobin (HGB), haematocrit (HCT), mean corpuscular volume (MCV), mean corpuscular hemoglobin $(\mathrm{MCH})$, mean corpuscular hemoglobin concentration (MCHC), red cell distribution width (RDWc), platelet count (PLT), platelet percentage (PCT), mean platelet volume (MPV) and platelet distribution width (PDWc)] were measured using an Automatic cell counter (Exigo, Veterinary Hematology System, Boule Medical AB, Stockholm, Sweden.). Furthermore, the blood samples were centrifuged (3200 rpm for 15 minutes). Subsequently, the blood plasma was collected and used for determination of aspartate amino transaminase (AST) and alanine amino transaminase (ALT) as indicators of liver functions. In addition, urea (BUN) and creatinine (CR) were determined as indices of kidney functions.

\section{Statistical analysis:}

Statistical analysis was performed using (SAS, 2005) and Student's t-test. The model used was: $\mathrm{Y}_{\mathrm{iR}}=\mathrm{U}+\mathrm{S}_{\mathrm{i}}+\mathrm{e}_{\mathrm{ik}}$

Where:

$\mathrm{Y}_{\mathrm{iR}}=$ observed value of the concerned trait.

$\mathrm{U}=$ observed mean for the concerned trait.

$\mathrm{S}_{\mathrm{i}}=$ the fixed effect due to housing system $\mathrm{e}_{\mathrm{ik}}=$ Random error

\section{RESULTS AND DISCUSSIONS}

Feed intake and growth performance:

The effects of an open or closed house system on rabbit performance are shown in Table 3. The heat stressed $(\mathrm{OHS})$ rabbits showed significantly $(\mathrm{P}<0.05)$ lower values of final body weight (FBW), DFI and DWG than close house group. Moreover, the CHS group recorded the best $(\mathrm{P}<0.05)$ FCR compared to (OHS). There was no mortality observed during the experimental period in both OHS and CHS. The adverse effect of high AT on rabbits may be due to the fact that rabbits born during hot months grew slower in addition to the lower FI which may be due to depressed thyroid activity and hence metabolic rate (Darwish et al., 1995 and Abdel-Azeem et al., 2007) and to the low metabolizable energy left for growth, since more energy is consumed through increasing respiratory frequency that occurs in hot ambient temperature (Habeeb et al., 1993) and Marai and Habeeb (1998) reported that high environmental temperatures stimulate peripheral thermal receptors to transmit suppressive nerve impulses to the appetite centre in the hypothalamus causing a decrease in rabbit FI. Depression in FI is the most important reaction to heat exposure (Marai et al., 1994, 2002, \& 2006 and Marai and Habeeb, 1994, 1998 and Okab and El-Banna, 2003 and Okab et al., 2008). These results are in agreement with those reported by Ayyat and Marai (1998) and Marai et al., (1991) who found that the exposure of rabbits to a high AT decreases growing live BW. A decrease in ADG of $18 \%$ was observed when rabbits were exposed to high environmental temperature (Chiericato et al., 1992).

\section{Carcass characteristics:}

The data reported in Table (4) showed that neither CHS nor OHS had significant effects $(\mathrm{P} \geq 0.05)$ on most of the carcass traits percentages, such as: dressing, heart, liver, thyroid gland, head, lungs, ceacum and abdominal fat percentages as well as length of gastrointestinal tract (GIT) and ceacum. On the other hand, spleen and kidneys percentages were significantly higher $(\mathrm{P} \leq 0.05)$ in $\mathrm{CHS}$ than heat stressed rabbits (OHS). The contrary is true regarding the intestine percentage which was significantly higher in the heat stressed rabbits. Results obtained herein are in agreement with those of Ayyat and Marai (1998) and Zeferino et al. (2013) who stated that in rabbits heat stressed resulted in lower slaughter and carcass weights and proportional reductions of organ weights.

\section{Physiological responses:}

Complete blood counts or haematological analysis monitoring body condition, are shown therefore data obtained in Tables (5 and 6) and elucidate that neither OHS nor CHS had significant effects on most of blood picture parameters and liver and kidneys function in rabbits. However, WBC, LYM, MID and PDW were significantly higher in heat stressed (OHS) than CHS rabbits. Results of hematological and biochemical parameters of rabbits as affected by high AT are conflicting. Blood serum parameters were found to differ according to season of the year. In this connection, Ayyat and Marai (1998) indicated that AST and ALT activities were significantly lower during the summer than during the winter season due to the increase of water intake and, consequently, the increase in enzyme dilution during the hot conditions. Generally, the blood enzymes are easily and often, influenced by the external environment including feeding practices, type of shelter and many other aspects of herd management, since they are intimately related to metabolism (Marai et al., 2002).

Table 3. Effects of closed (CHS) and open (OHS) housing system on feed intake and growth performance of growing NZW rabbits (Means $\pm \mathrm{SE}$ )

\begin{tabular}{lccc}
\hline & CHS & OHS & P-Value \\
\hline Initial body weight, $\mathbf{g}$ & $727.7 \pm 67.88$ & $747.3 \pm 46.98$ & 0.813 \\
Final body weight, $\mathbf{g}$ & $2826^{\mathrm{a}} \pm 98.74$ & $2290^{\mathrm{b}} \pm 64.56$ & 0.001 \\
Daily Feed intake, $\mathbf{g}$ & $101.97^{\mathrm{a}} \pm 0.24$ & $97.38^{\mathrm{b}} \pm 1.13$ & 0.005 \\
Daily Body gain, $\mathbf{g}$ & $26.22^{\mathrm{a}} \pm 1.66$ & $19.29^{\mathrm{b}} \pm 0.94$ & 0.001 \\
Feed conversion ratio & $4.13^{\mathrm{b}} \pm 0.28$ & $5.22^{\mathrm{a}} \pm 0.26$ & 0.007 \\
\hline
\end{tabular}

Values in each row are means \pm Stander error of means for 40 replicates of each treatment.

Means within row with different superscripts are significantly different $(\mathrm{P} \geq 0.05)$ 
Table 4. Effects of closed (CHS) and open (OHS) housing system on carcass criteria and digestive organs of growing NZW rabbits (Means \pm SE)

\begin{tabular}{llll}
\hline & CHS & OHS & P-Value \\
\hline Dressing (\%) & $59.62 \pm 0.77$ & $60.58 \pm 0.80$ & 0.411 \\
Heart (\%) & $0.30 \pm 0.04$ & $0.30 \pm 0.01$ & 0.995 \\
Liver (\%) & $3.01 \pm 0.18$ & $2.64 \pm 0.16$ & 0.156 \\
Spleen (\%) & $0.10^{\mathrm{a}} \pm 0.01$ & $0.05^{\mathrm{b}} \pm 0.01$ & 0.003 \\
Thyroid gland (\%) & $0.02 \pm 0.003$ & $0.01 \pm 0.001$ & 0.102 \\
Kidney (\%) & $0.73^{\mathrm{a}} \pm 0.05$ & $0.53^{\mathrm{b}} \pm 0.03$ & 0.008 \\
Head (\%) & $4.065 \pm 0.24$ & $5.15 \pm 0.16$ & 0.121 \\
Lungs (\%) & $0.52 \pm 0.04$ & $0.43 \pm 0.01$ & 0.063 \\
Small intestine (\%) & $4.39^{\mathrm{b}} \pm 0.34$ & $5.38^{\mathrm{a}} \pm 0.22$ & 0.040 \\
GIT length (cm) & $371 \pm 43.44$ & $313 \pm 17.07$ & 0.244 \\
Rectum (\%) & $0.39 \pm 0.03$ & $0.41 \pm 0.03$ & 0.542 \\
Rectum length (cm) & $12 \pm 0.29$ & $12 \pm 0.63$ & 0.121 \\
Abdominal fat (\%) & $0.65 \pm 0.10$ & $0.59 \pm 0.12$ & 0.708 \\
\hline Values in each row are means $\mathbf{\%}$ Stander error of mean &
\end{tabular}

Values in each row are means \pm Stander error of means for 5 replicates of each treatment.

Means within row with different superscripts are significantly different $(\mathrm{P} \geq 0.05)$

Table 5. Effects of closed (CHS) and open (OHS) housing system on blood picture of growing NZW rabbits (Means \pm SE)

\begin{tabular}{|c|c|c|c|}
\hline Blood pictures & CHS & OHS & P-Value \\
\hline WBC $\left(10^{3} / \mathrm{mm}^{3}\right)$ & $2.433^{b} \pm 0.81$ & $12.333^{\mathrm{a}} \pm 2.92$ & 0.031 \\
\hline LYM (\%) & $1.433^{b} \pm 0.44$ & $6.633^{a} \pm 1.52$ & 0.031 \\
\hline $\operatorname{MID}(\%)$ & $0.70^{\mathrm{b}} \pm 0.21$ & $3.00^{\mathrm{a}} \pm 0.76$ & 0.043 \\
\hline GRA $(\%)$ & $0.333 \pm 0.14$ & $2.733 \pm 1.26$ & 0.130 \\
\hline $\operatorname{RBC}\left(10^{6} / \mathrm{mm}^{3}\right)$ & $4.02 \pm 1.80$ & $5.210 \pm 0.57$ & 0.563 \\
\hline $\operatorname{HGB}(g / d l)$ & $11.333 \pm 0.81$ & $10.567 \pm 1.20$ & 0.624 \\
\hline HCT (\%) & $37.633 \pm 2.28$ & $33.300 \pm 4.05$ & 0.404 \\
\hline $\operatorname{MCV}$ (fl) & $62.433 \pm 1.53$ & $63.733 \pm 1.39$ & 0.564 \\
\hline MCH (pg) & $18.767 \pm 0.67$ & $20.267 \pm 0.76$ & 0.213 \\
\hline MCHC(g/dl) & $30.067 \pm 0.52$ & $31.800 \pm 0.75$ & 0.131 \\
\hline RDW $(\%)$ & $18.133 \pm 2.19$ & $16.567 \pm 1.04$ & 0.553 \\
\hline $\operatorname{PLT}\left(10^{3} / \mathrm{mm}^{3}\right)$ & $329.667 \pm 124$ & $405.333 \pm 114$ & 0.678 \\
\hline MPV (fl) & $4.600 \pm 0.26$ & $6.200 \pm 0.52$ & 0.059 \\
\hline РСТ\% & $0.253 \pm 0.01$ & $0.240 \pm 0.05$ & 0.789 \\
\hline PDW\% & $16.767 \pm 0.13^{b}$ & $17.700 \pm 0.06^{\mathrm{a}}$ & 0.003 \\
\hline
\end{tabular}

Values in each row are means \pm Stander error of means for 10 replicates of each treatment. Means within row with different superscripts are significantly different $(\mathrm{P} \geq 0.05)$

WBC: White blood cell, HCT: Hematocrit, MCV: Corpuscular volume, MCH: Corpuscular hemoglobin, MCHC: Corpuscular hemoglobin concentration, MPV: Platelet Volume, PDW: Platelet distribution width, PLT: Platelets, RDW: Red blood cell distribution width, PCT: Thrombocrit

Table 6. Effects of closed (CHS) and open (OHS) housing system on liver and kidney functions of growing NZW rabbits (Means \pm SE)

\begin{tabular}{lccc}
\hline Items & CHS & OHS & P-Value \\
\hline UREA & $57.667 \pm 5.24$ & $59.66 \pm 4.18$ & 0.780 \\
CREATININE & $0.973 \pm 0.30$ & $1.533 \pm 0.13$ & 0.162 \\
ALT & $59.33 \pm 10.73$ & $55.66 \pm 15.94$ & 0.585 \\
AST & $60.66 \pm 10.52$ & $78.33 \pm 7.06$ & 0.236 \\
\hline
\end{tabular}

Values in each row are means \pm Stander error of means for 5 replicates of each treatment.

\section{CONCLUSION}

It can be stated that reared growing New Zealand White rabbits to OHS decreased growth performance but did not have any significant effects on carcass traits, liver and kidney functions as well as digestive organs. However, more research is needed in future to evaluate reproductive performance and economical return of rabbits under Upper Egypt climate.

\section{REFERENCES}

Abdel-Azeem, A.S., A.M. Abdel-Azim, A.A. Darwish and E.M. Omar, 2007. Body weight and carcass traits in four pure breeds of rabbits and their crosses under Egyptian environmental conditions. The $5^{\text {th }}$ International Conference on Rabbit Production in Hot Climates, Hurghada, Egypt, 67-80. 
Aduku, A.O. and J.O. Olukosi, 1990. Rabbit management in the tropics: Production, Processing, Utilization, Marketing, Economics, Practical training, Research and Future Prospects, Living Book Services, G.U. Publications, Abuja, Nigeria.

Ayyat, M.S. and I.F.M. Marai, 1998. Evaluation of application of the carcass traits and blood components of New Zealand White rabbits fed various dietary energy-fibre levels. Egyptian 7th Conference Animal Nutrition (Ruminants, Poultry and Fishes), El-Arish, North-Sinai, Egypt, pp. 551-564.

Casimiro, C., H. Eugenio and L. Fabio, 1991. Performance of rabbits in hot climate and using "cooling system" for heat stress reduction. Ciheam-Options Mediterraneennes, 17: 463-467.

Chiericato, G. M., L. Bailoni and C. Rizzi, 1992. The effect of environmental temperature on the performance of growing rabbits. Journal of Applied Rabbit Research, 15: 723-730.

Dacinia-Crina Petrescu, Ioan G. Oroian, Tania Mihăiescu, Laura Paulette, Dan Vârban and C.,Tudor Pătruţoiu, 2013. Rabbit statistics overview: production, trade, market evolution. Rabbit Genetics, 3(1): 15-22.

Darwish, A.A., M.A. Khalifa, Abd A.M. El-Azim, and E.M.A. El-Kamash, 1995. Some physiological reactions of New Zealand White under subtropical conditions. In: Proceeding of 7th Annual Congress (Under Patronage of the Egyptian Society for Animal Reproduction and Fertility), 21-23 January, Cairo, Egypt 123-141.

Habeeb, A.A., A.I. Aboul-Naga and H.M. Yousef, 1993. Influence of exposure to high temperature on daily gain, feed efficiency and blood components of growing male Californian rabbits. Egyptian Journal Rabbits Science, 3 (1): 73-80.

Kanaly, R, A., Lea I.O. Manzanero, Gerard Foley, Sivanandam Panneerselvam and Darryl Macer, 2010. Energy Flow, Environment and Ethical Implications for Meat Production. Bangkok, Regional Unit for Social and Human Sciences in Asia and the Pacific (RUSHSAP), UNESCO Bangkok.

Marai, I.F.M., A.M. abdel-samee and M.N. ElGafaary, 1991. Criteria of response and adaptation to high temperature for reproductive and growth traits in rabbits. Ciheam-Options Mediterraneennes, 17: 127-134.

Marai I.F.M. and A.A.M. Habeeb, 1994. Thermoregulation in rabbits. Options Mediterraneennes 8: 33-41.

Marai I.F.M., A.A.M. Habeeb, El-Sayiad G.A. and M.Z. Nessem, 1994. Growth performance and physiological response of New Zealand White and Californian rabbits under hot summer conditions of Egypt. Options Mediterraneennes 8: 619-625.

Marai I.F.M. and A.A.M. Habeeb, 1998. Adaptation of Bos taurus cattle under hot climate conditions. Annals of Arid Zone 37: 253-281.

Marai I.F.M., M.S. Ayyat and U.M. Abd ElMonem, 2001. Growth performance and reproductive traits at first parity of New Zealand White female rabbits as affected by heat stress and its alleviation, under Egyptian conditions. Tropical Animal Health and Production, 33: 112.

Marai, I.F.M., A.A. Habeeb, and A.E. Gad, 2002. Rabbits' productive, reproductive and physiological performance traits as affected by heat stress: A review Livestock Production Science, 78: 71-90.

Marai I.F.M., A.A. Askar and L.B. Bahgat, 2006. Tolerance of New Zealand White and Californian doe rabbits at first parity to subtropical environment of Egypt. Livestock Science 104: 165-172.

Okab A.B. and S.G. El-Banna, 2003. Physiological and Biochemical Parameters in New-Zealand white Male Rabbits during spring and summer seasons. Egyptian Journal of Basic and Applied Physiology 2:289-300.

Okab A.B., S.G. El-Banna and A.A. Koriem, 2008. Influence of environmental temperatures on some physiological and biochemical parameters of male New-Zealand rabbits. Slovak Journal of Animal Science 41: 12-19.

SAS, 2005. User's Guide: Statistics. Version 9.2. SAS Institute, Inc., Cary, NC, USA.

Zeferino, C.P., C.M. Komiyama, S. Fernandes, J.R. Sartori, P.S. Teixeira and A.S. Moura, 2013. Carcass and meat quality traits of rabbits under heat stress. Animal, 7(3):518-523. 
أثر ظروف الإسكان على الآداء الإتتاجي والفسيولوجي لأرانب النيوزيلندي الأبيض النامية

عبدالله حسن حسين علي، أحمد أبوبكر عبدالمنعم عبدالوارث

قسم الإتتاج الحيوانسي والدواجن، كلية الزراعة،-جامعة جنوب الوادي، قنا، مصر

تهدف هذه الدراسة الي تقييم الأداء الإنتاجي وصفات الذبيحة و الاستجابة الفيسيولوجية لأرانب النيوزيلندي النامية في كل من نظام الاسكان

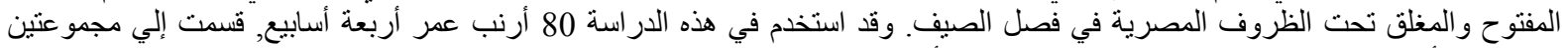

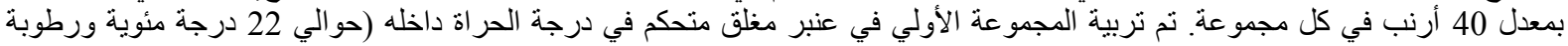

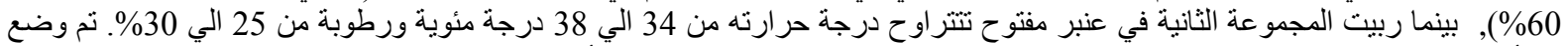

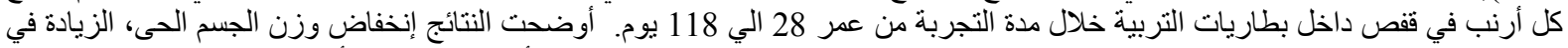

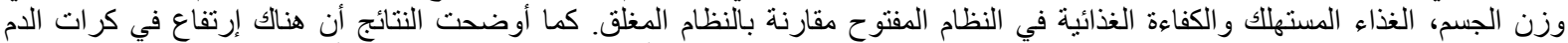

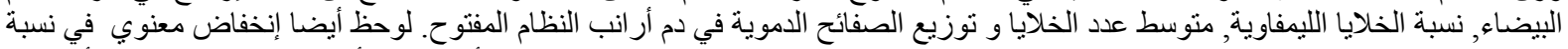

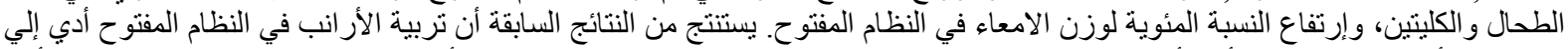

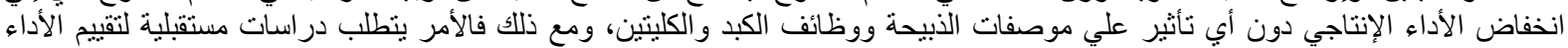

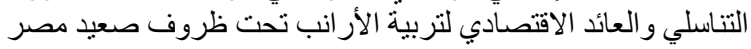

